\title{
MUSCULOSKELETAL COMPLICATIONS AND GENERAL HEALTH STATUS OF INDIVIDUALS WITH SICKLE CELL DISEASE
}

\author{
*O Ayanniyi; *AOZ Ayeni and **MO Oni-Orisan \\ *Department of Physiotherapy, College of Medicine, University of Ibadan, Ibadan, Nigeria. \\ **Department of Community Medicine, College of Health Sciences, AUTECH, Osogbo Campus.
}

\author{
Corresponding Author \\ *O Ayanniyi \\ mckdalos@yahoo.com
}

\section{SUMMARY}

Sickle cell disease is a chronic disease that is associated with high degree of morbidity and mortality. The objective of this study was to find the relationship between musculoskeletal complications and general health status of patients with sickle cell disorders.

The HSQ 2.0 questionnaire, (a general health survey questionnaire), was used to assess the subjects' health status while a separate questionnaire was used to compile data on complications. Descriptive and inferential statistic of Spearman's correlation was used to find relationship between complications and health status. Level of significance was set at 0.05 alpha.

Seventy-two subjects with sickle cell disorder participated in the study. Fifty-six (77.8\%) were of genotype Hb SS. Most of the subjects, 51 (70.8\%) normally experienced back pain, 22 (30.5\%) had chest pain while only $2.8 \%$ had visual problem. Generally, subjects scored low on all health status sub-scales except the mental health sub-scale where the mean score was near $60 \%$ (59.84 \pm $17.41 \%)$. The lowest mean score $(47.99 \pm 24.03 \%)$ was obtained on role limitation due to physical health sub-scale. There were significant correlations between complications and health status.

It was concluded that the health of individuals with sickle cell disease is compromised on all the eight domains of health status and that painful complications affect their social and physical functioning and impose limitation on them. It was also concluded that the more the number of body parts with pain the lower the health status become.

KEYWORDS: Musculoskeletal complications; Health status; Sickle cell disease.

\section{INTRODUCTION}

Sickle cell anemia is a genetic disease characterized by the production of abnormal hemoglobin (Hb) (Callahan et al, 2002). It is a pathological condition characterized by the presence of hemoglobin $\mathrm{S}$ (HbS) (Scutelleri et al, 2003). It occurs predominantly in people of African descent (Nemours Foundation, 2005), it was estimated that about 90,000 babies with sickle cell disease are born yearly in Nigeria (Akinyanju, 1989).

Hallmark of sickle cell disease include pain, stroke, anemia and major organ complications.

There are three types of sickle cell crisis in the adult population; the most common is the very painful-vaso-occlusive crisis, which results from tissue hypoxia and necrosis due to inadequate blood flow to a specific region of tissue or organ (Smeltzer and Bare, 2003). The Vaso -occlusive crisis or sickle cell crisis is a common painful complication of sickle cell disease in adolescents and adults and acute episodes of severe pain (crisis) are the primary reasons that these patient seek medical care in hospital emergency departments (Steven et al, 2000).

Although the disease disrupts organ functions throughout the entire body, modern medical management has extended the life span of most patients from less than 20 years to more than 50 years (Serjeant and Serjeant, 2004), and more people with sickle cell disorders in Nigeria are now surviving beyond their third decade (Ohaeri and Shokunbi, 2001). Callahan et al (2002) and Serjeant and Serjeant (2004) opined that due to repeated vaso occlusive crisis over the years, there is chronic as well as acute tissue damage.

Sickle cell crisis can cause both acute and chronic tissue damage affecting almost any organ in the body; and therefore compromising the patients' quality of life, (Shirley, 1972). Kater et al, (1990) submitted that in children, sickle cell disease leads to compromised physical and psychological well being, as well as the experience of decreased independence in daily functions. Quality of life is deteriorated by episodic, debilitating pain associated with 
substantial analgesic use and frequent hospitalizations (McClish et al, 2005).

Health status measure can have multiple applications; in research setting, health status measure instruments can be used to quantify disease severity and disability or access guidelines and treatment options. In practice, functional outcome measures might be used to enhance the clinical setting by facilitating proper communication and guiding treatment and management strategies (AAP, 2005). Therefore assessing the health status of patient with sickle cell disease may be an important method for providing health care practitioner who care for these patients a more objective perspective on the impact and severity of this disease and can as well guide treatment and management strategies.

The study sought to know; the prevalence of known musculoskeletal complications like back pain, hip pain leading to avascular necrosis of femoral head, leg ulceration and others among individuals with sickle cell disorders in Nigeria; the relationship between the numbers of body parts with painful musculoskeletal complications and the general health status of the individual with sickle cell disease; and which aspect of individuals with sickle cell disorders health is mostly affected.

\section{METHODS}

Patient Sample: Patients were recruited from the Hematology departments, Physiotherapy out Patient clinics and Sickle cell clinics of some Hospitals in South West of Nigeria. The study involved patients who have been clinically diagnosed of sickle cell disease and are between the ages of 16 years and above.

Seventy-two male and female patients that have been clinically diagnosed with sickle cell anemia disease ( $\mathrm{Hb} \mathrm{SS}, \mathrm{Hb} \mathrm{SC}, \mathrm{Hb} \mathrm{SF}$ and $\mathrm{HbS}$ Thallasemia) with their age within the range of 1635 years completed the questionnaires in this study.

Measures Number of body parts with pain: The instruments used for this study was: A questionnaire that was specifically designed by the researcher consists of 13 items (list of complications that are associated with sickle cell disease), with section for demographic data; genotype, age and sex. This was done in a way to allow for the patient to write their genotype if not listed. Space is also left for the patient to write any other complication that is not listed.

Health Status: General Health status questionnaire HSQ-2.0; is very similar to short form (SF-36) general health status questionnaire was used. It is scored using a Likert scale (Yeomans, 2002) HSQ2.0 uses eight scales and measure three aspects of health (functional status, well being and overall evaluation of health). The eight scales are: Physical functioning, social functioning, and Role limitation due to physical health, Role limitation due to emotional health, mental health, Bodily pain, Energy/fatigue and General health perception (Garat et al, 1993; Yeomans, 2002). It has a validity of 0.85 and a test retest reliability of 0.80 (Garat et al, 1993).

The health status questionnaire was translated to Yoruba language and back translated to English language to ensure that the meaning of the questionnaire was retained during translation.

\section{Procedure}

Informed Consent and Ethical Approval: Ethical approval was sought and obtained from the University of Ibadan and University College Hospital; Institutional Review Committee before the commencement of this study. The permission of the consultants in charge of the Clinics were also sought and obtained. The rationale for the study and the details of the procedure were adequately explained to the subjects after which their informed consent was sought and obtained. The questionnaires were given to subjects to complete while the researcher waited to collect the completed copies.

\section{Treatment of Data}

Scoring of the Instrument: The data sheet was scored by coding a "yes" response to be 1 and “No" response to be zero (0) (Araoye, 2003). The total score for each patient was computed. The H.SQ-2-0 was decoded and scored for eventual data analysis. The scores on each scale were calculated by - scoring up the decoded scores and dividing by the number of items in each scale.

Total score on a scale

Number of items in the scale

The higher the result (score) the better that individual on the scale

Data Analysis: The data were analyzed; both descriptive and inferential statistics were used to summarize the data.

(a) Descriptive statistic of mean and standard deviation were calculated for age and scores on health status scales.

(b) Frequency distribution was computed for sex, genotype and painful complication.

(c) Spearman's correlation coefficient was used to determine the correlation coefficient between score on painful complication and each scale of health status.

The significance level was set at 0.05 . 


\section{RESULTS}

Seventy- two, (38 males and 34 females), sickle cell patients successfully completed the questionnaires. Thirty-Eight (58.2\%) male and the mean age and standard deviation of the subjects was $23.64 \pm 4.64$ years with a range of $16-35$ years. Twenty (27.8\%) subjects were within the age range of 16 and 20 years while nine (12.6\%) subjects were above the age of 30 years.

Fifty-Six (77.8\%) of the subjects were of Genotype HbSS. Ten subjects (13.9\%) were HbSC; only two (2.8\%) subjects were of thalasemia variant, four patients did not indicate their genotype.

Prevalence of Complication: Sixty-five (90.3\%) of the subjects normally experienced general bone pain, Fifty-one (70.8\%) subjects agreed to be having back pain, forty-six (63.9\%) of the subjects experienced knee pain from time to time.
Hip pain was common to Thirty-eight (52.8\%) of subjects. (Figure 1).

The results also showed that thirty-five (53.8\%) of the sixty-five subjects that normally have general bone pain were male. Thirty-one (60.8\%) of subjects with back pain were male. Twenty- one (55.3\%) female subjects have hip pain. (Figure 2).

Score on health status scale Table 1 displays the mean and standard deviation with minimum and maximum score on each of the general health status scale. The highest was score was on mental health scale where the mean was $59.84 \pm$ 17.41.

Table 2 shows the Spearman's correlation coefficients between the numbers of body parts with pain and each of the eight-sub- scale of general health status scale.

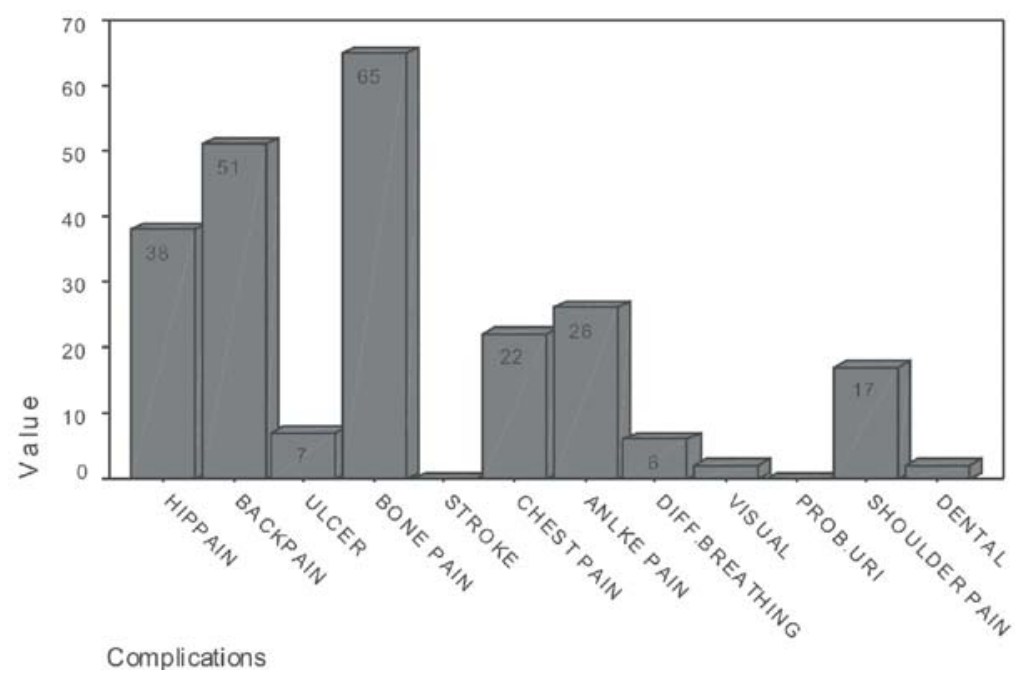

Fig. 1: Prevalence of Complication among the Subjects.

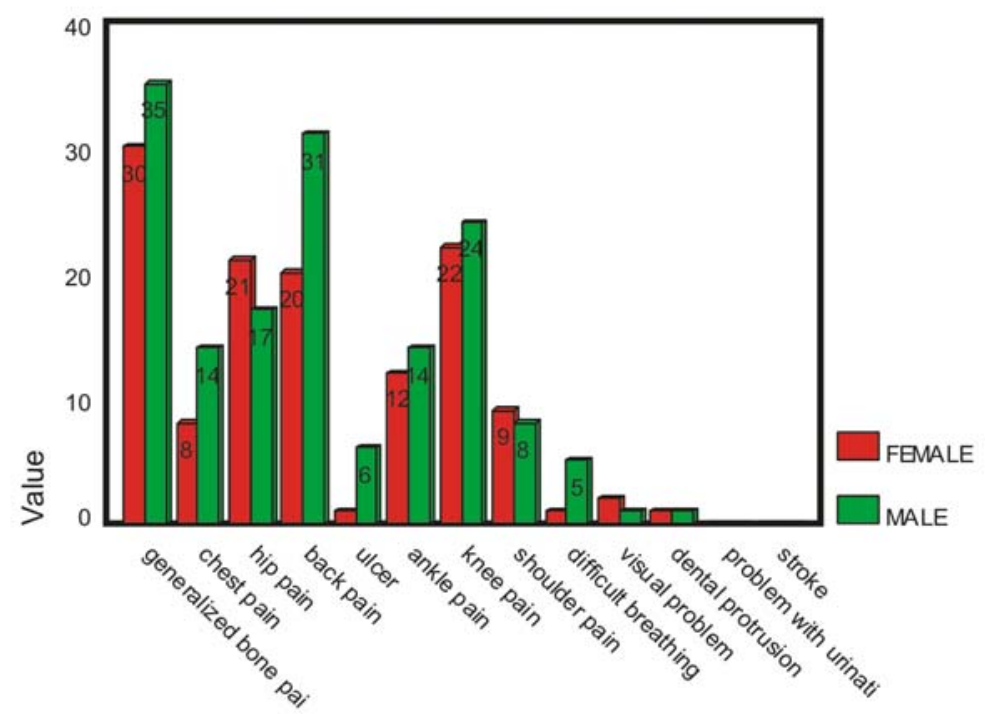

COMPLICATIONS

Fig. 2: Distribution of complications among male and female subjects. 
Table 1: Score on Health Status Sub-Scales.

\begin{tabular}{lcccc}
\hline & Minimum & Maximum & Mean & Std. Deviation \\
\hline $\begin{array}{l}\text { Health Perception } \\
\text { Physical Functioning }\end{array}$ & 27.00 & 100.00 & 53.5694 & 16.0464 \\
$\begin{array}{l}\text { Role limitation } \\
\text { (Physical Health) }\end{array}$ & 25.00 & 100.00 & 54.0972 & 17.5292 \\
Role limitation & .00 & 100.00 & 47.9861 & 24.0255 \\
$\begin{array}{l}\text { Emotional Health) } \\
\text { Social functioning }\end{array}$ & .00 & 100.00 & 49.5321 & 27.9680 \\
Mental Health & .00 & 100.00 & 52.9861 & \\
Bodily Pain & 36.00 & 96.00 & 59.8472 & 17.4143 \\
Fatigue & 22.50 & 100.00 & 55.3472 & 20.8503 \\
\hline
\end{tabular}

Table 2: Correlation coefficients between Number of body parts with pain and health status sub-scales.

\begin{tabular}{|c|c|c|c|c|c|c|c|c|c|}
\hline & & $\begin{array}{l}\text { Health } \\
\text { Percep- } \\
\text { tion }\end{array}$ & $\begin{array}{l}\text { Physical } \\
\text { Functio- } \\
\text { ning }\end{array}$ & $\begin{array}{l}\text { Role } \\
\text { Limitation } \\
\text { (Physical } \\
\text { Health) } \\
\end{array}$ & $\begin{array}{l}\text { Role } \\
\text { Limitation } \\
\text { (Emotional } \\
\text { Health) } \\
\end{array}$ & $\begin{array}{l}\text { Social } \\
\text { Functioning }\end{array}$ & $\begin{array}{l}\text { Mental } \\
\text { Health }\end{array}$ & $\begin{array}{l}\text { Bodily } \\
\text { Pain }\end{array}$ & Fatigue \\
\hline \multirow{2}{*}{$\begin{array}{l}\text { Number of } \\
\text { Body Parts } \\
\text { with pain }\end{array}$} & $\begin{array}{l}\text { Correlation } \\
\text { Coefficient }\end{array}$ & -.048 & $-.435 * *$ & $-.356 * *$ & $-.297 *$ & $-.264^{*}$ & -.038 & $-.298 *$ & $-.253^{*}$ \\
\hline & $\mathrm{N}$ & 72 & 72 & 72 & 72 & 72 & 72 & 72 & 72 \\
\hline
\end{tabular}

\section{DISCUSSION}

The age range of subjects involved in this study was between 16 and 35 years with nine (12.6\%) of the subjects being above the age of 30 years. This supports the assertion by Platt et al, (1994) that sickle cell disorders can no more be referred to as a disease of childhood and that of Ohaeri and Shokunbi, (2001) that more individuals with sickle cell disorders are now surviving beyond the age of 30 years in Nigeria.

Fifty-six (77.8\%) of the patients were HbSS while $13.9 \%$ were HbSC. This is in contrast to the findings of Gladwin and Rodgers (2004) that reported $69 \%$ for SS and $1 \%$ for SC in a population of 195 patients. In a study involving 537 patients by Vichinsky et al, (2000), in the United States, percentage of SS was $82 \%$, the percentage recorded for SC is higher in contrast to what is reported by Mcclish et al, (2005).This high frequency of SC variant may be due to the fact that HbSC trait occur in about $6 \%$ of the Yoruba in the southwest of Nigeria (Akinyanju, 1989).

Sixty-five (90.3\%) of the subjects had general bone pain frequently, this was the component with highest prevalence. Thirty five (53.8\%) were male while thirty $(46.2 \%)$ were females.

The prevalence of hip pain in the study population, which was $52.2 \%$ may be connected with the prevalence of avascular necrosis of head of femur, which normally results from persistent pain at the hip, as high number of vaso oclusive crises has been said to be associated with osteonecrosis (Adekile et al, 2001). The sex distribution of $44.74 \%$ male and $55.30 \%$ females may be because the prevalence of hip arthritis is more in female than in male as observed by Ingvarson et al (1999) where $52.5 \%$ of subjects with hip arthritis were females. In a study by Alonge and Shokunbi (2004), 60\% of the reported cases of avascular necrosis of head of femur resulting from sickle cell anemia were females.

Furthermore, the prevalence of back pain, which was $70.8 \%$, makes it the second most common site of pain. This high prevalence is supported by the findings of Serjeant et al, (1994) who reported prevalence of $75 \%$ in crises emanating from lumbar origin and that they noted as the most common site of painful vaso occlusive crisis. The sex distribution of back pain cannot be attributed to anything as back pain has been said to affect both male and female equally in the general population (Anderson, 1999). Prevalence of knee pain in the study population was $63.9 \%$. This finding is in contrast to the findings of Serjeant et al, (1994) where the prevalence of knee pain was recorded as $32.2 \%$ among the Jamaican sickle cell population. The sex distribution of $52.2 \%$ male and $47.8 \%$ female may be a reflection of the subject selection, as knee pain has not been documented to be sex related in sickle cell disease.

Prevalence of ankle pain in the study population was $36.1 \%$. Serjeant et al, (1994), did not record the prevalence and no known study has recorded the prevalence in patients with sickle cell disease, this may be because it is not common among patients with sickle cell disease 
in other geographical areas. Prevalence of shoulder related- pain was $23.6 \%$. This finding agrees with that of Serjeant et al, (1994) that reported the prevalence of shoulder pain to be $12 \%-23 \%$ in 183 crises recorded in 118 sickle cell patients. Sex distribution has not been documented by any known studies.

Also only 7(9.7\%) had leg ulceration, out of which $6(85.7 \%)$ were male and 1 (14.3\%) female. This low prevalence of leg ulceration is in agreement with the report by Serjeant, (1994) that leg ulceration and other end organ damage are not common in West Africa. Also according to the United States Department of Health and Human Services (USHHS, 2002); leg ulceration is more common in male than in female sickle cell patients.

None of the seventy-two subjects that took part in this survey had stroke or had suffered from stroke before. This is in agreement with previous findings by Akinyanju (1989) who reported that stroke is not common among people suffering from sickle cell disease in Nigeria.

Chest pain was reported in 22(30.5\%) subjects, out of which $14(63.6 \%)$ were male and $8(33.4 \%)$ were female. This value did not support the findings of Serjeant et al, (1994) that reported $18 \%$ incidence for pain at the sternum and $17 \%$ for pain associated with ribs.

In the results of this study, the mean score and standard deviation on the health status scale was $53.57 \pm 16.01$. This was at variance with the findings of McClish et al (2005) where the documented mean and standard deviation was $39.2 \pm 22.1 \%$ in a U.S population of sickle cell patients. The result is however similar to the findings by DeOreo (1997) and by Lee and Sullivan (2003) that reported values of $50.0 \pm$ $22.4 \%$ and $57.9 \pm 19.0 \%$ for patients undergoing hemodialysis and asthmatic patients respectively. The value obtained from this study was however lower than the $72 \%$ reported by Ware et al (1993) for an average American citizen.

The result showed that the mean score and standard deviation on the physical functioning scale was $54.09 \pm 17.53 \%$. This finding is at variance to the findings of McClish et al, (2005), as the mean score from their study was 62.4. \pm $29.4 \%$ this result is also lower to the findings by Lee and Sullivan (2003) in Asthmatic patients in United States which was $63.2 \pm 29.4 \%$. And lower than the result from the findings of Gee et al (2002) in cystic fibrosis patients where the documented mean was $76.3 \pm 24.0 \%$. The finding of DeOreo (1997) in the study involving patients undergoing hemodialysis is however lower than the mean in this study as the documented value on this $44.3 \pm 27.8 \%$ scale. The value obtained from this study was however lower than the $84 \%$ reported by Ware et al (1993) for an average American citizen. This showed that the studied population scored lower than their counterpart on physical functioning sub scale.

The mean score and standard deviation on the role limitation due to emotional health scale in this study population was $49.53 \pm 27.97 \%$, Over half of the population (54\%) scored below $50 \%$ mark and $12.5 \%$ of the population scored above the $66.66 \%$ mark. The mean for this scale in this study is in contrast to $57.8 \pm 43.1 \%$ that McClish et al, (2005) reported in their study. Average value in normal population in the United States on this scale is $81 \%$.

Mean score on the role limitation due to physical health scale was $(47.98 \pm 24.03 \%)$ is not in agreement with the findings of McClish et al, (2005) as the documented mean for this scale for U.S sickle cell population was $39.2 \pm 39.4 \%$. It is also higher than the finding of Lee and Sullivan in the study involving asthmatic patients with the documented value of $38.7 \pm 39.9 \%$ than that of patient undergoing hemodialysis (39.7 $\pm 40.4 \%$ ) as documented by DeOreo (1997). The value obtained from this study was however lower than the $81 \%$ reported by Ware et al (1993) for an average American citizen.

In the results of this study the mean value on the social function scale $(52.98 \pm 21.48 \%)$ is in contrast to the findings of McClish et al, (2005) in the U.S sickle cell population (63.5 \pm 25.27$)$. This goes to show that physical functioning of patients with sickle cell disease in the studied population is greatly impaired.

The findings of this study showed that the mean value and standard deviation on the body pain scale in the study population (55.35 \pm 20.85 $\%$.) is higher than what is available in the sickle

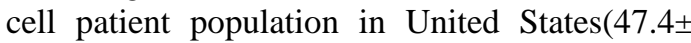
27.2\%) as documented by McClish et al (2005). This could be because some complications like leg ulceration, stroke and some other end organ damage that can contribute to crisis and pain are not common around here as reported by Akinyanju (1989) and Sergeant (1993). The mean value from this study is however lower than that of the hemodialysis patients (60.4 \pm 29.1\%) DeOreo(1997), cystic fibrosis patients(82.2. \pm 21.3\%) Gee et al (2002), and asthma patients (67.2 \pm 23.2.1\%) Lee and Sullivan (2003) thus suggesting that sickle cell patients suffer more bodily pain.

The result of this study indicated that the mean score in energy and fatigue scale was 52.64 \pm 18.54 with $33.3 \%$ of the subjects scoring above $61 \%$. This findings is in contrast to the finding of McClish et al, (2005) where the mean score on this scale which is $42.7 \pm 22.5 \%$ for United State of America sickle cell patient population, it 
is also higher than the mean score of hemodialysis patient given by DeOrco (1997)as $46.5 \pm 22.3$ and that of asthma given by Lee and Sullivan (2003) as $48.2 \pm 20.8$ but lower than the mean value for the cystic fibrosis population in the United State of America given as $58.4 \pm 23.1$ by Gee et al, (2002).

The study population scored highest on the mental health scale compared to the scores on other scales. The mean score in this scale was $59.84 \pm 17.41 \%$. This is consistent with the findings of McClish et al, (2005) for sickle cell population in the U.S.

Several limitations of the study should be noted.

First the sample size was small; this was because of unwillingness of many patients to take part in the study because of stigma attached to the disease. Secondly there was no standard normative value for normal individuals to really compare the values gotten with. Another limitation was the fact that the study was confined to South West of Nigeria, and therefore may not be representative of the entire Nigeria Sickle Cell Disease population.

\section{CONCLUSION}

There was negative correlation between number of painful musculoskeletal areas and health status of subjects with sickle cell disease. Painful complications affect social and physical functioning of patients with sickle cell disease and as well impose limitation on them but Mental health and health perception of the population of patients with sickle cell disease studied are not influenced by painful complication.

Recommendations: health care provider involved in the management of patients with sickle cell disease should regard sickle cell patients health status as been compromised so that every treatment should be used as an opportunity for counseling. Physiotherapists should be more involved in the management of individuals with sickle cell disease as many of the modalities at the disposal of Physiotherapists could be used in the management of painful complications thereby improving the patients' health status and quality of life. Health status and quality of life measures should be included in the assessment and evaluation of individuals with sickle cell disease.

\section{REFERENCES}

- Adekile A. D., Gupta R, Yakoub F, Sinan T, Albouish M. Haider M. Z, (2001): Avascular Necrosis of hip in children with sickle cell disease and high HbF. Magnetic Resonance Imaging findings and influence of á thalasemia trait. Acta Hematologica 105: 1.
- Akinyanju O. O. (1989): A profile of sickle cell in Nigeria: Annals of the New York Academy of Science: 565 (1): $126-136$.

- Alonge T. O; Shokunbi W. A. (2004): The choice of Arthroplasty for secondary osteoarthritis of the hip joint following avascular necrosis of the femoral head in sicklers. Journal of the National Medical Association 96: 5678 - 681 .

- American Academy of Pediatrics (AAP) (2005): Functional outcome project: Why are outcome measures for children important? "http://www.aap.org/research/impoutcome.html" 2/9/05, 2.30pm.

- Anderson G.B. J. (1999) Epidemiology features of chronic low back pain Lancet 354: 581 - 585.

- Araoye MO (2003): Data processing and analysis Research methodology with statistics for health and social sciences

Nathadex publishers, Ilorin, 160-163.

- Callahan A. L; Woods K.F; Mensah G.A; Ramsey L.T; Barbeu P; Gutin B (2002): Cardiopulmonary Responses to Exercise in Women with sickle cell Anemia. American Journal of Respiratory and Critical Care Medicine, 165: 1309-1316.

- DeOreo PB (1997): Hemodialysis patient assessed functional health status predicts continue survival, hospitalization and dialysis attendance compliance. America Journal of Kidney Disease, 30: 204-212.

- Gee L; Abbott J; Conway S P; Etherington C; Webb A K (2002): Validation of the SF-36 for the assessment of quality of life in adolescents and adults with cystic fibrosis. Journal of Cystic Fibrosis, 1: 137 - 145.

- Geralt M. A. and Ruta A. D (1993): The SF-36 health survey questionnaire: An outcome measure suitable for routine use with the NHS. British Medical Journal, 306: 1140 - 1444.

- Gladwin, M.T and Rodgers G. P. (2000): Pathogenesis and Treatment of acute chest Syndrome of sickle cell anemia. The Lancet. 355: $1476-1478$.

- Ingvarson T, Haggland G, Lohmanedah S. L (1999): Sex difference in hip osteoarthritis: Annals of rheumatic disease 58: 201-207.

- Kater AP; Heijboer H; Peter M; VogelsT; Prin MH; Heyman HS(1999):quality of life in children with sickle cell disease in Amsterdam area. Netherland Tidschrift voor Geneeskund 143 (41): 2049-2053 (abstract).

- Lee T. A, Hollingworth W, Sullivan (2003): Comparison of directly elicited preferences to preferences derived from the SF-36 in adults with asthma. MDM, 23: 323-334. 
- McClish KD, Penberthy TL, Bovbjerg EV, Robert DJ, Aisiku PI Levenson LJ (2005): health related quality of life in sickle cell patients. Health and Quality of Life Outcome 3, 50: Doi: 10.1186/1477-7525-3-50.

- Nemours Foundation (2004): Sickle Cell Anemia. $\mathrm{Http} / / \quad$ kidshealth.org/teen/disease 12:15pm 12/01/05.

- Ohaeri, J.U. and Shokunbi, W.A. (2002): Psychosocial burden of sickle cell disease on Caregivers in a Nigerian setting. Journal of the National Medical Association. 94: 1058-1070.

- $\quad$ Platt, O.S; Donald, J; Wendel, F.R; Milner, F.P; Oswaldo, C; Steinberg, M.H; Klug, P.P. (1994): Mortality in sickle Cell disease, life expectancy and risk factors for early death. New England Journal of Medicine. 330:1639-1644.

- Scutellari, P.N; Cinott. A; Cunco A; Mannella P(2003): Avascular Necrosis in sickle cell Disease (on line). http://www.euroad.org/case.cfm?UID=2181 5.30PM. 10.01.05.

- Serjeant G.R. (1993): The Geography of sickle cell disease: Opportunities for Understanding Its

Diversity: http://www.kfshrc.edu/SA/ANNALS/143/Rev92 39.html.3.50pm 16/01/05.

- Serjeant G.R. and Serjeant B.E. (2004): Sickle cell in Saudi Arabia: The Asian haplotype Reflection on a meeting at Hofuf September 2003. Annals of Saudi Medicine. 24: 3.

- Serjeant G.R., Ceulaer CD; Lethbridge R; Morris J.S; Singhal A; Thomas P.W. (1994):
The painful crisis of homozygous sickle cell disease; clinical features, British Journal of Heamatology 87; 586-591.

- Shirley M.L. (1972): Sickle cell; A complete guide to prevention and treatment. Pavilion Publishing Company New York 15-16.

- Smeltzer S.C. And Bare B. ( 2003): Brunner \& Suddarth's Textbook of Medical-Surgical Nursing $10^{\text {th }}$ Edition. Lippincott Williams. 36: 886-888.

- Steven H. Y, Nahed N; Troy G; (2000): Approach to sickle

vaso-occlusive crisis in Adults With sickle cell disease. American Family Physician.

- USHHS (2002): United state department for health and human services: management of sickle cell disease, handout. www.nhlbs.nih.gov/health/prof/blood/sickle. 12/12/2003. 14: 25hrs.

- Vichinsky E. (2002): Rapid Review: New Therapies in sickle cell disease. The Lancet 360: 629-631.

- Ware J. E. jr and Sherbourne C. O. (1992). The 36 item short form health survey (S-F-36). Medical care 30: 473 - 483.

- Yeomans S G: (2001): General health questionnaires. Outcome assessment. 